\title{
The Influence of Forms of Insurance Coverage Organization on Population's Life Quality
}

Kaigorodova G.N.

Kazan Federal University, Institute of Management, Economics and Finance, Kazan, 420008, Russia

Mustafina A.A.

Kazan Federal University, Institute of Management, Economics and Finance, Kazan, 420008, Russia

\section{Doi:10.5901/mjss.2014.v5n24p118}

\section{Abstract}

Social insurance is essential for the development of population's quality of life because it fulfils social functions such as lowincome citizens support; and economic functions such as the renewal of human resources; the development of the voluntary insurance market due to the increase in effective demand. For historical reasons, there are different types of correlation between compulsory social and voluntary insurance. These types depend on the stage of the development of national economies of countries, as well as from the historically formed principles of social security. Each type has its own purposes, negative and positive sides. Furthermore, we should not forget the specific features of each national economy

Keywords: population's quality of life, social insurance, commercial insurance, compulsory insurance, insurance premiums per capita

\section{Introduction}

Insurance, undoubtedly, plays a significant role in improvement of population's quality of life. The development of social security in this connection is of great importance. We can mark out the following interrelation. As a rule, the state is at the beginning of chain of interrelation. It receives mandatory contributions from population for the development of social security including insurance. Further, social security allows to renew human resources which, in turn, ensure the development of social security.

Voluntary, private, and commercial insurance is a different story. In this case, the demand for insurance resources is created by clients of insurance companies. In this regard, availability of customers funds (i.e., the effective demand for insurance services) is of considerable importance. However, a lack of appropriate funds among potential customers of insurance companies slows the development of voluntary insurance.

In result we have a kind of the vicious circle: insurance, certainly, has a high impact on quality of life, but, at the same time, the insurance development depends on the level of the effective demand, i.e. on the quality of human resources.

It is obvious that, as a rule, the state is at the head of the vicious circle of insurance market development (as an important factor of the population's quality of life). So, the state makes appropriate infusion in the form of mandatory payments to the development of social security; it affects the development of voluntary insurance as well.

\section{Theory}

The size of premiums on the insurance market depends on the population's income level and unemployment rate, and it correlates with the level of premiums per capita. We researched the interrelation of the marked factors within the framework of the Russian national economy for the period from 1998 until 2013. It should be noted that the analysis of the insurance market potential, as well as factor analysis of the relationship between endogenous and exogenous variables, has been performed at various times by many researchers. We can mark an insurance potential assessment model proposed by Shipitsyna S.E., who has built a system of indicators to assess the insurance potential of the region. However, the proposed factors that, according to the author, reflect the insurance potential of the region characterize a current state of the insurance market rather than its insurance potential. Among the indicators are: insurance market concentration, ratio of insurance premiums attributable to one company, volume of premiums, etc. All these indicators do not assess the insurance potential, they describe the result of insurance companies activities. The current state of the 
insurance potential does not respond to the question of interest for insurers-nonresidents of the market - whether to enter this market at the moment when the entry barriers have not become a serious problem for access. The author, however, offers an interesting methodology to assess the insurance potential through its relationship with the investment potential. Unfortunately, at the time of assignment of a high credit rating and, hence, a high rating of the investment potential to a particular region, the entry barriers in the market increase rapidly due to the sharp increase in the market competition.

We also should note a study of the link between real life insurance premiums per capita and real gross domestic product (GDP) per capita for 41 countries within three levels of income covering 1979-2007 [1].

The authors came to the following conclusions. First, empirical results reveal that the traditional panel unit-root tests could lead to misleading inferences. Second, for the estimated half-lives, the degrees of mean reversion are greater in high-income countries. Third, there is concrete evidence favoring the hypothesis of a long-run equilibrium relationship between real GDP and real life insurance premiums after allowing for the heterogeneous country effect. The long-run estimated panel parameter results indicate that a $1 \%$ increase in the real life premium raises real GDP by $0.06 \%$. Finally, it was determined that the development of life insurance markets and economic growth exhibit long-run and short-run bidirectional causalities. These findings offer several useful insights for policy-makers and researchers.

However, the authors sometimes omitted the fact that in some countries, such as Russia, life insurance is often binding (a voluntary form is not developed due to the lack of effective demand) and the state is on the top of life insurance. It means that, life insurance does not develop with the necessary degrees of freedom. Further, we mark out a study that incorporates multiple structural breaks to investigate whether property-casualty insurance (PCI) premiums per capita among 40 countries are mean-reverting or not. The results suggest that the panel dataset is stationary. However, after introduction of the structural breaks into the model and consideration of cross-sectional dependence the results for the test vary with regard to different country characteristics. The researchers came to the following conclusion: any external shocks can have a permanent effect on the insurance premiums. Accordingly, the associated insurance authorities should take possible structural breaks into account when implementing related policies [2]. Thus, such investigations should cover a wider period of time to include possible structural breaks.

Also we can mark an study of the effectiveness of insurance industry of the national economies within the international insurance market conducted according to 6462 insurers from 36 countries. The study is interesting for us because it considered the dependence of the efficiency of life and non-life insurance on special features of national economy, organizational form, size of insurance companies, etc. The researchers concluded that Denmark and Japan have the highest average efficiency, whereas the Philippines is the least efficient [3].

Economists conducted studies of the efficiency of voluntary insurance market within the BRIC countries [4]. The researchers found that the environment affects the efficiency of non-life insurers operating in the BRIC countries. Furthermore, the authors identified four drives of efficiency: Size, profitability, solvency, and ownership form. In our opinion, the analysis should take into account the historically formed redistribution of social and voluntary insurance in the country, in its context the BRIC countries differ essentially from each other.

Also, we will note a study providing an overview of the literature linking health, health insurance and labor market outcomes such as wages, earnings, employment, hours, occupational choice, job turnover, retirement, and the structure of employment. The empirical literature surveyed suggests that poor health reduces the capacity to work and has substantive effects on wages, labor force participation and job choice. Also the empirical literature suggests that access to health insurance has important effects on both labor force participation and job choice; the link between health insurance and wages is less clear [5].

Lets us introduce the marked factors of analysis. Insurance premiums (contributions) is a payment for the insurance that the insured (or beneficiary) shall pay to the insurer in the manner and within the time limits established by the contract of insurance. Income of the population is defined as a sum of all cash receipts of the population from various sources that is available for current consumption and savings, except for money withdrawn from previously accumulated savings and received by the population in the form of loans (credits). Income is determined on the basis of the sum of separate components.

In accordance with the current methodology (No. 61 approved by the State Statistics Committee of Russia as of July 16,1996$)$ when determining the total income of population it is necessary to consider the data on wages and social benefits paid to employees, income from business and property, social payments (in the form of pensions, benefits, scholarships and other measures of social support) formed on the basis of official statistical reporting of organizations making payments to the population. Cumulative assessment of income includes increase of the volume of cash income generated in the informal sector of economy. The said increase is taken as equal to the difference between the total expenditure and savings growth of the population and the total cash payments to the population accounted on the basis of official statistical reporting of organizations. Unemployment rate is the ratio of the unemployed of a certain age group to 
the economically active population (employed and unemployed) of the respective age group in percentage terms. The data on the economically active population employed in economy and the unemployed are obtained on the basis of sample surveys on employment conducted by Russian statistical authorities with the following extrapolation of results to the entire population of the surveyed age. The survey has been conducted in Russia since 1992. In 1992-1994, 1997, and 1998 it was conducted one time per year as of the last week of October; in 1995 - 2 surveys were conducted as of the last week of March and October; in 1996 - 1 survey as of the last week of March; since the year 1999 until August, 2009 the survey was conducted on a quarterly regularity. Beginning from September, 2009 the survey is carried out on a monthly basis. Observation units are households and persons at the age of 15-72 years, members of these households. More than 69 thousand people at the age from 15 to 72 years ( $0.06 \%$ of the population in this age group) were polled during each survey. A varying sampling ratio based on the total population and a relative variation of the "unemployment" indicator is chosen for each constituent entity of the Russian Federation. The sample is based on the primary data base of All-Russia Population Census (ARPC-2002) containing information on the resident population i.e. who are permanently resident in the territory of the region, city, village.

\section{Results}

The panel study showed that the highest correlation is observed between the average per capita income (0.9) and insurance premiums per capita ( 0.95 ), which was supposed by us earlier (Table 1). At the same, time the relationship between the insurance premiums and the unemployment rate cannot be traced, the correlation was 0.1. Note that, unlike the unemployment rate, the employment rate of the population has a greater correlation with the dynamics of insurance premiums (0.86).

Table 1. Insurance premiums / marked factors correlation for the period of 1998-2013

\begin{tabular}{|l|c|c|c|}
\hline & Per capita income, thous. RUR & Unemployment rate, in\% & Insurance premiums per capita, RUR. \\
\hline Insurance premiums, mln. RUR & 0.933 & 0.148. & 0.952 \\
\hline
\end{tabular}

Thus, the availability of economically active, employed population with corresponding income allows the insurance market to develop. The state implements appropriate market stimulation through social insurance and, thus, allow the voluntary insurance market to develop.

Besides the empirical analysis, the influence of factors on the insurance market development should be also viewed in a psychological aspect, because the market development also depends on the consumers' behavior. When we talk about the potential demand for insurance services, we have to mention what affects the development of demand for insurance services besides the funds availability. According to a survey conducted by Oliver Wyman Company and Rating Agency "Expert RA", the behavior of retail customers in Russian insurance market continues to affect the cost of insurance products, while corporate clients prefer to take out insurance from large well-known insurance companies, as well as from those with which corporate customers have developed long-term positive economic relations. Thus, according to $80 \%$ of the surveyed insurers, the retail customers targeted at cheap products, and $85 \%$ of insurers said that corporate clients prefer to take out insurance from major insurance companies [6]. According to a pool conducted by the Rating Agency "Expert RA", 12\% of insurers noted that after the crisis clients of insurance companies began to choose only reliable insurance companies, and that will affect the growth of the cost of services of large insurers and the outflow of potential customers with less effective demand from the market [7].

The correlation between social and voluntary insurance. The present article should answer the following questions. What is more important for improvement of life quality - the development of social or voluntary commercial insurance? In our opinion, social insurance has the greatest impact on population's quality of life; but it should not be all-encompassing, it should not obstruct a commercial voluntary form of insurance. The correlation between social and voluntary insurance should be 60:40, where 60\% - a level of social security of the population and $40 \%$ - commercial insurance development. Thus, compulsory insurance must leave people a right and motivation to pay attention to a voluntary commercial form of insurance development. In favor of the existence and high level of social security we can mention a study whose author proved that a high level of social security is correlated with a high level of professional growth of the population [8]. The negative aspect of a high level of social security in comparison with voluntary insurance may be an increase of leadingstrings mentality among the population, which, in turn, can lead to a high level of unemployment in the country. Low demand for insurance services in this case results in decrease in quality of offered insurance services. Possible changes in the structure of social security were offered by the authors of the following study [9]. 
In our opinion, social insurance is essential for the improvement of population's quality of life, because it fulfils social functions such as low-income citizens' support; and economic functions such as the renewal of human resources, the development of the voluntary insurance market due to the increase in effective demand. But at the same time a strong bias in favor of social security bears negative factors. Thus, social insurance reduces the economic freedom of the population as a kind of tax and does not depend on the population wishes. The excessive development of social insurance increases a bias in favor of compulsory insurance, thus pulling the demand off from the market of voluntary insurance services, and at the same time it reduces economic competition in the insurance market and increases dependence of the insurance market on compulsory insurance, reducing the activity of insurance companies in improvement of the quality of offered services. We offer the following correlation matrix.

\begin{tabular}{|c|c|c|}
\hline \multirow{3}{*}{ 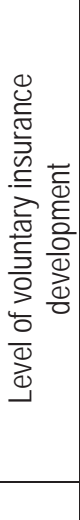 } & $\begin{array}{l}\text { Dependence of insurance coverage on } \\
\text { population's income which reduces the } \\
\text { quality of life. } \\
\text { High degree of economic freedom of the } \\
\text { population. Improvement of competition } \\
\text { in the insurance market }\end{array}$ & $\begin{array}{l}\text { Dependence of insurance coverage on population's income which reduces } \\
\text { the quality of life. } \\
\text { Low degree of economic freedom }\end{array}$ \\
\hline & $\begin{array}{l}\text { Low level of population's quality of life } \\
\text { Low level of protection against the risks } \\
\text { associated with reproduction of the labor } \\
\text { force }\end{array}$ & $\begin{array}{l}\text { High level of population's quality of life. } \\
\text { Low degree of economic freedom of the population. } \\
\text { High level of leading-strings mentality among the population, as a } \\
\text { consequence: increase in the number of immigrants, a negative state of } \\
\text { migration policy. } \\
\text { Lobbying of own interests on the part of insurers. Insurers' unwillingness to } \\
\text { improve the quality of insurance services. }\end{array}$ \\
\hline & & Level of social security development \\
\hline
\end{tabular}

Fig. 1 Matrix of correlations between social and voluntary insurance and the quality of life of population

It is interesting that in the countries where social insurance is not developed voluntary insurance develops due to employers interested in the improvement of human resources. For historical reasons, there are different types of correlation between compulsory social and voluntary insurance. These types depend on the stage of the development of national economies of countries, as well as from the historically formed principles of social security.

Let us consider these types. The first two types are: social security state depending on a type of economy: developed or developing. In developing economies, as a rule, social security is not developed, as the development course is targeted at the achievement of a high level of development by all means, in this connection the human capital is only consumed by economy, and the market is not interested in the availability of people of retirement age. The state of developed economy is reflected on the increase of the number of long-living people, due to a high level of health services, quality of life, etc. This contributes to the need for a high level of social security.

The case may be exemplified by the developing economy of China; its social security is underdeveloped for several reasons. Among these reasons are the following. First, the government has set the goal to show fast economic growth; the economy does not bear social character; human resources are only consumed by the economy, there is no incentive for their reproduction. Social security in such conditions will draw off a part of economic growth and will slow the implementation of the economy objective - which is the level of a developed system. Second, specific feature of China national economy is a high amount of economically active population, which is currently growing old rapidly. This circumstance does not allow the country to increase social welfare.

An example of a developed economy with a high level of social security is the national economy of Japan. In due course this developed economy has passed all stages of a developing economy when social security has been neglected. However, after transition to the developed type of national economy social security began to attract more and more attention to itself. Japan is known for the greatest number of long-livers.

The next two types of correlations: historically established balance in favor of social security or voluntary insurance. This can be exemplified by national economies of Russia and the United States. The national economy of Russia beginning from the time of the social type of economy has developed a high level of human resources social security. The example is interesting for the interrelation of premiums ratio in the insurance market and the degree of the market's "level of development" proposed by Oliver Wyman, within which the distinct premium ratios are considered depending on the "level of development" of economies [10].

We can see historically development of voluntary insurance in the USA economy, that resulted in the evolution of 
competition in the insurance market. The economy's specific feature is that, despite assurances from President Obama on the revision of social policy for the purpose of public support increase, the lobby in the insurance market does not allow USA to implement the previously announced reform. The following study is interesting in the context of the history of voluntary life insurance. Analysis of the life insurance holdings of male probated decedents in Ontario in 1892 demonstrates a negative correlation between the level of personal wealth and the demand for life insurance. Consistent with the study self-insurance was a substitute for market purchases of life insurance where self-insurance capabilities are a by-product of wealth accumulation. The study shows that households primarily demanded life insurance when they lacked accumulated reserves, or wealth, for self-insurance, often early in the life cycle [11]. Thus, initially, life insurance depends on the availability of the effective demand.

Each type has its own purposes, negative and positive sides. Furthermore, we should not forget the specific features of each national economy. Table 2 shows the types of social security of economies.

Table 2. Types of social security of economies

\begin{tabular}{|c|c|c|}
\hline & Developed economy & Developing economy \\
\hline $\begin{array}{l}\text { Historically formed } \\
\text { imbalance towards } \\
\text { social security. }\end{array}$ & $\begin{array}{l}\text { Purpose - social security of population, improvement of } \\
\text { population's quality of life, civilized level of development. } \\
\text { Disadvantages - draw of a part of economic growth to social } \\
\text { security, growth suppression, leading-strings mentality, } \\
\text { migration growth, migration policy revision, changes in } \\
\text { structure of the historically formed residential population. } \\
\text { Advantages - reproduction of the human capital, civilized } \\
\text { level of development. } \\
\text { Example: the economy of Japan, France, etc. }\end{array}$ & $\begin{array}{l}\text { Purpose - rapid development of the } \\
\text { economy. } \\
\text { Disadvantages - draw of a part of } \\
\text { economic growth to social security, growth } \\
\text { suppression, leading-strings mentality. } \\
\text { Advantages - reproduction of the human } \\
\text { capital. } \\
\text { Example: the economy of Russia, } \\
\text { Kazakhstan, etc. }\end{array}$ \\
\hline $\begin{array}{l}\text { Historically formed } \\
\text { imbalance in favor of } \\
\text { voluntary insurance }\end{array}$ & $\begin{array}{l}\text { Purpose - a civilized level of development. } \\
\text { Disadvantages - limit of population's quality of life. } \\
\text { Advantages - economic freedom of population, absence of } \\
\text { leading-strings mentality among the population. } \\
\text { Example: the U.S. economy, etc. }\end{array}$ & $\begin{array}{l}\text { Purpose - rapid development of the } \\
\text { economy. } \\
\text { Disadvantages - the consumption of } \\
\text { human resources without reproduction due } \\
\text { to the lack of effective demand, limit of } \\
\text { population's quality of life. } \\
\text { Advantages - no draw of forces to non- } \\
\text { economic objectives. } \\
\text { For example, economies of China, India. }\end{array}$ \\
\hline
\end{tabular}

\section{Conclusions}

Firstly, the panel study showed that the highest correlation is observed between the average per capita income (0.9) and insurance premiums per capita (0.95), which was supposed by us earlier (Table 1). At the same, time the relationship between the insurance premiums and the unemployment rate cannot be traced, the correlation was 0.1 . Note that, unlike the unemployment rate, the employment rate of the population has a greater correlation with the dynamics of insurance premiums (0.86). The availability of economically active, employed population with corresponding income allows the insurance market to develop. The state implements appropriate market stimulation through social insurance and, thus, allows the voluntary insurance market to develop. The economic behavior of retail customers in Russian insurance market continues to affect the cost of insurance products, while corporate clients prefer to take out insurance from large well-known insurance companies, as well as from those with which corporate customers have developed long-term positive economic relations.

Secondly, social insurance is essential for the development of population's quality of life because it fulfils social functions such as low-income citizens support; and economic functions such as the renewal of human resources; the development of the voluntary insurance market due to the increase in effective demand. But at the same time a strong bias in favor of social security bears negative factors. Thus, social insurance reduces the degree of economic freedom of population as a kind of tax, and does not depend on population's wishes. The excessive development of social insurance increases a bias in favor of compulsory insurance, thus pulling the demand off from the market of voluntary insurance services, and at the same time it reduces economic competition in the insurance market and increases dependence of the insurance market on compulsory insurance, reducing the activity of insurance companies in improvement of the quality of offered services.

Thirdly, for historical reasons, there are different types of correlation between compulsory social and voluntary 
insurance. These types depend on the stage of the development of national economies of countries, as well as from the historically formed principles of social security. Each type has its own purposes, negative and positive sides. Furthermore, we should not forget the specific features of each national economy.

\section{References}

Chien-Chiang Lee, Chi-Chuan Lee, Yi-Bin Chiu. The link between life insurance activities and economic growth some new evidence Original Research Article Journal of International Money and Finance, February 2013; 32: 405-427

Chien-Chiang Lee, Chun-Ping Chang, Pei-Fen Chen Further evidence on property-casualty insurance premiums: Do multiple breaks and country characteristics matter? Original Research ArticleJapan and the World Economy, Volume 24, Issue 3, August 2012, pp.215-226

Eling M., Luhnen M. Efficiency in the international insurance industry: A cross-country comparison. Original Research Article Journal of Banking \& Finance July 2010. pp. 1497-1509

Wei Huang, Eling M.An efficiency comparison of the non-life insurance industry in the BRIC countries Original Research Article European Journal of Operational Research, 1 May 2013. pp.577-591

Janet Currie, Brigitte C. Madrian Chapter 50 Health, health insurance and the labor market Review Article Handbook of Labor Economics, 1999. pp. 3309-3416

A Survey among Managers of Insurance Companies. Analysis of Oliver Wyman. 2011. pp. 1-96

The results of the survey of top managers of insurance companies at the forum "The Future of the Insurance Market" // Bulletin of the Rating Agency Expert Advisor Ra. November 10, 2010;

Giacomo Corneo Work norms, social insurance and the allocation of talent Original Research ArticleJournal of Public Economics, November 2013; 107: 79-92

Miropol'skaya N., Safina L., Fakhrutdinova E., Karasik E., The Role of Social Protection in Formation of Quality of Work Life, World Applied Sciences Journal 27 (Economics, Management and Finance), 2013. pp. 77-81 http://www.oliverwyman.com

Livio Di Matteo, J.C. Herbert Emery Wealth and the demand for life insurance: evidence from Ontario, 1892 Original Research Article Explorations in Economic History, October 2002. pp. 446-469.

Garifova L.F., Kundakchyan R.M., Pratchenko O.V. Integral Estimate of Socio-Ecological-Economic Factors on the Quality of Life of Population of the Region // Mediterranean Journal of Social Sciences. - Vol.5, No12, (2014)-pp. 117 - 121.

Askhatova L.I., Bulnina I.S. Quality-of-life (QOL) improvement as a strategic resource of sustainable social and economic development of a region. Life Science Journal $2014 ; 11(6 s)$ : 354-357.

Novenkova A.Z.,, Antonova N.V. Assessing Public Administration and Image Making Efficiency in the Region Taking Into Consideration Quality of Managing Black Economy// Mediterranean Journal of Social Sciences.- Vol.5, No12, (2014)-pp.167 - 171.

Bagautdinova N.G., Safiullin L.N., Mubarakov I.A. The Role of Quality of Goods in Formation of Consumer Choice// Mediterranean Journal of Social Sciences.- Vol.5, No12, (2014)-pp.63-68. 